


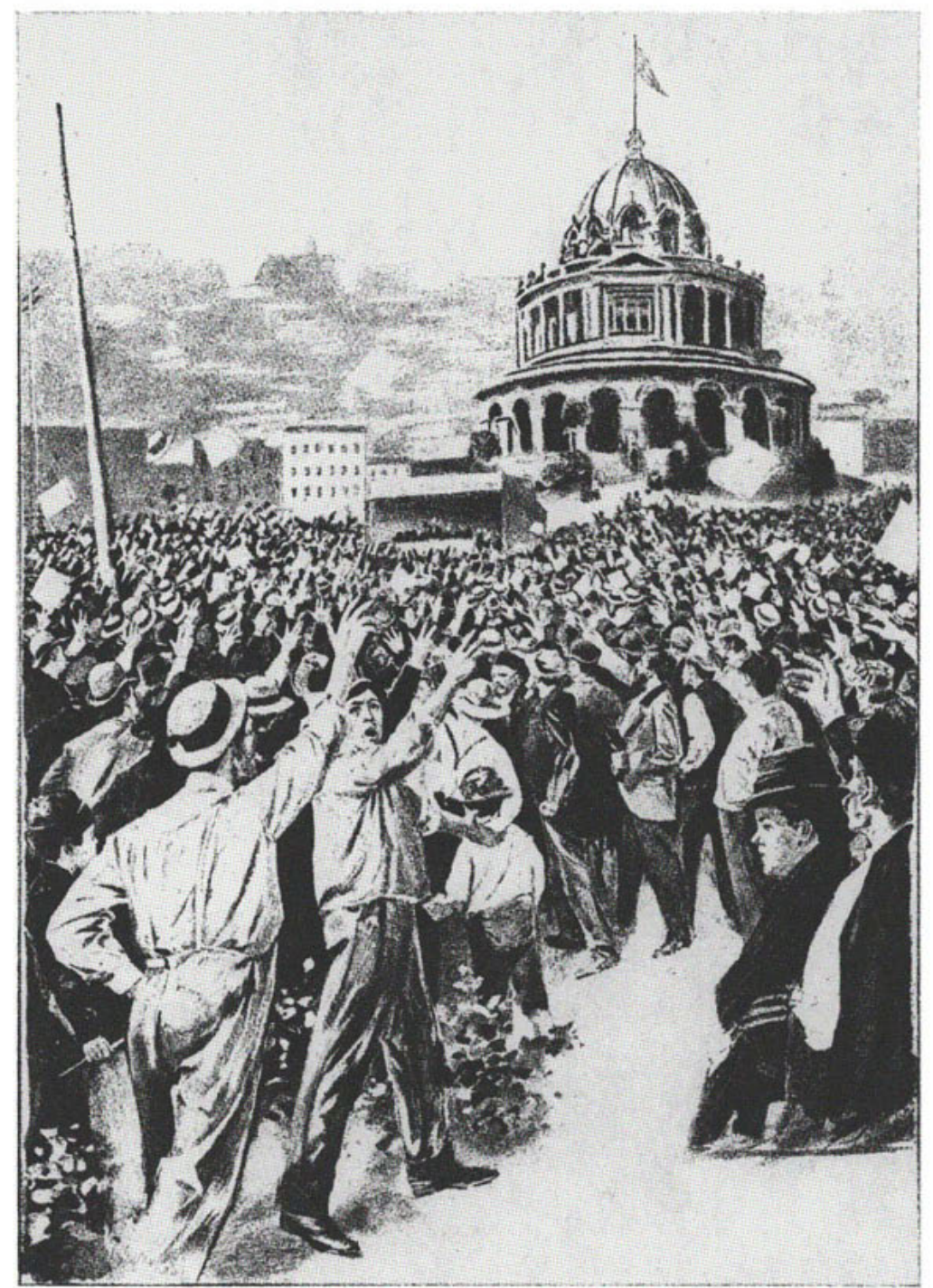

A SAND-LOT MEETING IN SAN FRANCISCO 


\title{
A HISTORY OF THE LABOR MOVEMENT IN CALIFORNIA
}

\author{
BY \\ IRA B. CROSS \\ PROFESSOR OF ECONOMICS ON THE FLOOD FOUNDATION \\ IN THE UNIVERSITY OF CALIFORNIA
}

UNIVERSITY OF CALIFORNIA PRESS

BERKELEY, LOS ANGELES, LONDON

1935 


\title{
University of California Publications in Economics
}

VOLUMe 14

\author{
Copyright, 1935 \\ BY THE
}

Regents of the University of California

\section{University of California Press \\ Berkeley, California}

University of California Press, Ltd.
London, England

California library Reprint Series Edition, 1974

ISBN 0-520-02646-2

Library of Congress Catalog Card Number 73-93026 
Affectionately Dedicated to J OH N R. COM M O S

Inspiring Teacher and Friend 
